Egyptian Journal of Aquatic Biology \& Fisheries

Zoology Department, Faculty of Science,

Ain Shams University, Cairo, Egypt.

ISSN $1110-6131$

Vol. 22(5): 387- 402 (2018)

www.ejabf.journals.ekb.eg

\title{
Effect of stocking density and feeding rate of Oreochromis niloticus on water quality and abundance of phytoplankton in aquaculture earthen ponds
}

\author{
Ahmad M. Azab ${ }^{1}$; Hassan M. M. Khalaf-Allah' ${ }^{1}$; Abd El-Rahman A. Khattaby ${ }^{2}$; \\ Ahmed S. M. Sadek ${ }^{3}$; Enas Galal Mansour ${ }^{2}$ and Mohammed O. M. Abdel-Ghany ${ }^{3}$ \\ 1- Zoology Depart., Faculty of Science, Al-Azhar University, Cairo, Egypt \\ 2- Central Laboratory for Aquaculture Research - Abbassa, Sharkyia Governorate, Egypt. \\ 3- General Authority for Fish Resources \& Development, Egypt.
}

\section{ARTICLE INFO}

\section{Article History:}

Received: Nov. 5, 2018

Accepted:Dec. 15, 2018

Online: Dec. 25, 2018

Keywords:
Aquaculture
earthen ponds
Oreochromis niloticus
stocking density
feeding rate
water quality
phytoplankton
abundance

\begin{abstract}
The present work aimed to study the effect of stocking density and feeding rates of Oreochromis niloticus on water quality and abundance of phytoplankton in earthen ponds. This experiment was conducted in 12 earthen ponds at Parsik Culture, Idko, Behira Governorate, Egypt. The ponds have the same area of about 2 feddan with an approximately average depth of $1 \mathrm{~m}$. Monosex fries of Oreochromis niloticus reared for 214 days with different stocking densities and feeding rates $\left(\mathbf{T}_{1}\right.$ : stocking density of $6 \mathrm{fish} / \mathrm{m}^{3}$ with feeding rate of $2.5 \% ; \mathbf{T}_{2}$ : stocking density of $6 \mathrm{fish} / \mathrm{m}^{3}$ with feeding rate of $3.5 \% ; \mathbf{T}_{3}$ : stocking density of $8 \mathrm{fish} / \mathrm{m}^{3}$ with feeding rate of $2.5 \%$ and $\mathbf{T}_{\mathbf{4}}$ : stocking density of $8 \mathrm{fish} / \mathrm{m}^{3}$ with feeding rate of $3.5 \%$ ), each treatment had three replicates.

Results showed that the highest average values of salinity $(\% \circ)$, total dissolved solids (mg/l), hydrogen ion concentration, total hardness $(\mathrm{mg} / \mathrm{l})$ and total nitrite ( $\mathrm{mg} / \mathrm{l})$ were recorded in $\mathbf{T}_{\mathbf{1}}$ and $\mathbf{T}_{\mathbf{2}}$ (low stocking fish densities); while their lowest values were recorded in $\mathbf{T}_{\mathbf{3}}$ and $\mathbf{T}_{\mathbf{4}}$ (high stocking fish density). On the other hand, the highest average values of chlorophyll a ( $g / 1)$ were recorded in $\mathbf{T}_{\mathbf{3}}$ and $\mathbf{T}_{\mathbf{4}}$ and their lowest values were recorded in $\mathbf{T}_{\mathbf{1}}$ and $\mathbf{T}_{2}$. The highest average value of dissolved oxygen content $(\mathrm{mg} / \mathrm{l})$ was recorded in $\mathbf{T}_{\mathbf{2}}$ and $\mathbf{T}_{\mathbf{4}}$ (high feeding rate), while the lowest average was recorded in $\mathbf{T}_{\mathbf{1}}$ and $\mathbf{T}_{\mathbf{3}}$ (low feeding rate). Total nitrate (mg/l) and orthophosphate had the reverse trend of these results. The maximum average value in abundance of phytoplankton specimens was recorded in $\mathbf{T}_{\mathbf{4}}$ $\left(222728667 \pm 37584559\right.$ organism/l) and the lowest occurred in $\mathbf{T}_{2}$ $(156813467 \pm 22022381$ organism/l). The variations in phytoplankton abundance were generally non-significant between the different experimental treatments. Four divisions of phytoplankton were recorded in the experimental fish ponds; Chlorophyceae, Cyanophyceae, Bacillorophyceae and Euglinophyceae. The most abundant division in all experimental fish ponds was Chlorophyceae $(42.46 \%)$; followed by Euglinophyceae $(33.85 \%)$.The variations in abundance of these phytoplankton divisions were statistically significant.The phytoplankton abundance was greatly varied in each treatment ponds during different months of the experiment. Generally, it reached the highest averages during the period of September-November in all treatments, and the lowest averages were recorded during June. The results concluded that the highest stocking density $\left(8 \mathrm{fish} / \mathrm{m}^{3}\right)$ with low feeding rate $(2.5 \%)$ was positively correlated with best water quality and high abundance of phytoplankton in earthen ponds of Oreochromis niloticus.
\end{abstract}




\section{INTRODUCTION}

The aquaculture industry accounted for over $45 \%$ of all sea food consumed. That will have been projected to increase to $75 \%$ over the next years (FTU, 2007).

In Egypt, the total fish production in 2016 was estimated at 1706273 tons, of which $80 \%$ from aquaculture and $20 \%$ from natural fisheries. The production of Nile Tilapia, Oreochromis niloticus forms $68.6 \%$ from the total aquaculture and natural production in Egypt (GAFRD, 2016). Fish importance as the food source of animal protein was increased with the increases in demands (Azab et al., 2005). A great attention has been paid to establishment of fish farms. These farms could contribute partially in producing the demanded on animal protein sources consumed by human (Ashour et al., 2018).

Tilapia is an ideal candidate for worm water aquaculture. They received considerable attention in many countries because of their good aquaculture potential; they are widely distributed in the world. The importance of Oreochromis niloticus stems from biological reasons (fast growth, short food chain, high food conversion ratio, readily accepting the artificial feeds, ease of breeding in captivity, disease resistance, high fecundity), social reasons (good table food quality, good market price) and physical reasons (tolerant to a wide range of environmental conditions). These attributes, along with relatively low input costs have made tilapia widely cultured freshwater fish in tropical and subtropical countries (Soliman, 2015; Samir et al., 2017and Abdel-Naby et al., 2017).

However, the determination of stocking density for cultured tilapia is essential for the maximization of its production, profitability and sustainability. This is because stocking density is one of the factors that could potentially affect fish survival (Houde, 1977) and production performance (Luz \&Zanibonifilho, 2002), so it must be considered when determining the economic profitability of production systems (Gomes et al., 2000). Furthermore, the use of the appropriate density is a commercially beneficial operation, focusing on maximizing the utilization of the rearing system, water and financial resources (Fairchild \& Howell, 2001). The growth and production of fish depend on regulating the quantity of feeds required to produce the maximum growth and this can be achieved by variations in the feeding rates (Kheir \& Mohammed, 2001).

Management procedures (stocking densities, feeding rate, sediment removal, fertilizing) of fish ponds are the key to sustainable fish production and directly affect the ecological processes developing in the water column. The water quality management in the fish pond shows a direct influence on planktonic population, since fish ponds are shallow and constantly receive large nutrient loads (feed and fish waste) which contribute towards algal growth. Excessive phytoplankton growth could be avoided by limiting nutrients to plankton growth through fish feed deprivation periods. The length of the latter may be sufficient so that phosphorus and nitrogen may be depleted and phytoplankton abundance decreased (Turano et al., 2008 and Soltan et al., 2016).

In aquaculture, fish productivity mainly depends on aquaculture ecosystems, especially water quality. Poor water quality causes decrease of fish productivity, increase of production costs and risk of diseases. In addition, it has negative effects on the environment, human health, laborers and consumers. O. niloticus is one of the most important cultured freshwater fish over the world. $O$. niloticus can tolerate a wider range of environmental conditions such as $\mathrm{DO}, \mathrm{pH}, \mathrm{NO}_{3}, \mathrm{NO}_{2}$ and ammonia 
levels. Therefore, this fish can easily culture and adaptable to a wide range of environmental conditions (El-Sayed, 2006 and Ashour et al., 2018).

In the case of aquaculture, the maintenance of good water quality is of primary importance, so that excellent culture environment, adequate feed for optimal fish yield potential, and increase in plankton population may be achieved. Therefore, the present investigation aimed to analyze the effect of stocking density and feeding rates of Oreochromis niloticus on water quality and abundance of phytoplankton in aquaculture earthen ponds.

\section{MATERIALS AND METHODS}

\section{Fish and experiment design:}

This experiment was conducted in twelve aquaculture earthen ponds at Parsik Culture, Idko, Behira Governorate, Egypt. The ponds have the same area of about 2 feddan with an approximately average depth of $1 \mathrm{~m}$ and filled in through agriculture drainage water from El Khairy drainage. Monosex fries of Nile Tilapia, Oreochromis niloticus (initial length $=2.45 \pm 0.07 \&$ initial weight $=0.45 \pm 0.06$ ), reared for 7 months extended from May to November, 2016 (for 214 days) with different stocking densities and feeding rates $\left\{\left(\mathbf{T}_{1}\right)\right.$ : stocking density of $6 \mathrm{fish} / \mathrm{m}^{3}$ (25000 fry/ feddan) with feeding rate of $2.5 \%$; $\left(\mathbf{T}_{2}\right)$ : stocking density of $6 \mathrm{fish} / \mathrm{m}^{3}$ (25000 fry/ feddan) with feeding rate of $3.5 \%$; $\left(\mathbf{T}_{\mathbf{3}}\right)$ : stocking density of $8 \mathrm{fish} / \mathrm{m}^{3}$ (33000 fry/ feddan) with feeding rate of $2.5 \%$ and $\left(\mathbf{T}_{4}\right)$ : stocking density of $8 \mathrm{fish} / \mathrm{m}^{3}$ (33000 fry/ feddan) with feeding rate of $3.5 \%$, each treatment had three replications. Fish were fed twice daily, six days a week on diet containing $18 \%$ protein. All treatment fish were fed at feeding rate of $10 \%, 7 \%, 5 \%$ and $4 \%$ of fish biomass during May, June, July and August respectively. The rates of feeding were changes to $2.5 \%$ of biomass in treatments $\mathbf{T}_{\mathbf{1}} \mathbf{\&} \mathbf{T}_{\mathbf{3}}$ or $3.5 \%$ of biomass in treatments $\mathbf{T}_{\mathbf{2}} \mathbf{\&} \mathbf{T}_{\mathbf{4}}$ during September, October and November respectively. The feeding rate adjusted at monthly intervals, where the fish were randomly selected by dragging a net in the ponds, weighed; and the average fish weight was obtained and the monthly feed intake ( $\mathrm{g}$ feed / fish /month) was calculated for each bond. Half of the water volume, for all earthen ponds, was weekly replaced.

\section{Water analysis:}

Water samples were taken by a vertical PVC water sampler at depth of a half meter from the water surface. Samples at each pond of each treatment were mixed in a plastic bucket and a sample of 1 liter was placed in a polyethylene bottle and transferred to the laboratory for analysis.

Water quality of the ponds was checked every month to determine salinity, total dissolved salts (TDS), hydrogen ion concentration $(\mathrm{pH})$, dissolved oxygen (DO) and temperature $\left({ }^{\circ} \mathrm{C}\right)$ were measured in the ponds at the time of collection water sample. The alkalinity, total hardness $\left(\mathrm{mg} / \mathrm{l}\right.$ as $\left.\mathrm{CaCO}_{3}\right)$, nitrite $\left(\mathrm{NO}_{2}-\mathrm{N}\right)$, nitrate $\left.\left(\mathrm{NO}_{3}-\mathrm{N}\right)\right\}$, orthophosphate and chlorophyll a content $(\mu \mathrm{g} / \mathrm{l})$ were carried out in the Limnology and Plankton Laboratories of the Central Laboratory for Aquaculture Research (CLAR).

Total dissolved salts (TDS) were determined using a salinity-conductivity meter (model, YSI EC 300). Hydrogen ion concentration was measured with a $\mathrm{pH}$ meter (Model 25, Fisher Scientific). Temperature $\left(\mathrm{T}^{\circ} \mathrm{C}\right.$ ) and dissolved oxygen (DO, mg/l) were measured by using a digital oxygen meter (Model YSI 55). The concentration of alkalinity $(\mathrm{mg} / \mathrm{l})$, total hardness $\left(\mathrm{mg} / \mathrm{l}\right.$ as $\left.\mathrm{CaCO}_{3}\right)(\mathrm{APHA}, 1992)$, total nitrite $\left(\mathrm{NO}_{2}-\mathrm{N}\right.$, 
$\mathrm{mg} / \mathrm{l})$, nitrate $\left(\mathrm{NO}_{3}-\mathrm{N}, \mathrm{mg} / \mathrm{l}\right)$, orthophosphate $(\mathrm{mg} / \mathrm{l})$ and chlorophyll a content $(\mu \mathrm{g} / \mathrm{l})$ were measured by methods described in Boyd \& Tucker (1992).

Phytoplankton (\%):

One liter of water was monthly collected from each experimental fish pond in polyethylene bottles. Phytoplankton in the sample was concentrated by settling 1000 $\mathrm{ml}$ sample in a volumetric cylinder for about 24 hours after being preserved in lugols solution (APHA, 1992). One ml of sample was transferred into Sedgwick-Rafter cell and microscopically counted. Three replicates of each sample were investigated.

All phytoplankton organisms were counted to genus level and estimated as organisms per cubic meter, according to the following formula: $\mathrm{N}=\mathrm{n}(\mathrm{v} / \mathrm{V}) * 1000$

Where, N: Total number of phytoplankton per cubic meter, n: Average number of phytoplankton in $1 \mathrm{ml}$ of the sample, v: Volume of phytoplankton concentrates (ml). V: Volume of total water filtered (L).

Different phytoplankton genus was identified according to Bellinger and Sigee (2010). Phytoplankton species were belonging to four divisions, which are: green algae (Chlorophyceae), blue-green algae (Cyanophyceae), diatoms (Bacillariophyceae), and Euglena (Euglinophyceae) and different genus were identified and counted. All colonial, filamentous or unicellular organisms were counted as one unit (organism).

\section{Statistical analysis:}

Data of different phytoplankton divisions in different experimental groups were analyzed by using the All Pairwise Multiple Comparison Procedures by Holm-Sidak Method (Holm, 1979) at 95\% confidence. Also, these data were analyzed by grouping information using the Tukey Pairwise Comparison Method (Tukey, 1949) at 95\% confidence of data was conducted by using Microsoft Excel and SPSS under windows programs.

\section{RESULTS}

\section{Water quality:}

Results of water quality of Oreochromis niloticus fry, reared in 12 earthen ponds for seven months with different stocking densities and feeding rates were given in Table (1).

Data in Table (1) showed that, the highest average value of salinity $(2.10 \pm 0.87$ $\%$ o) was recorded at $\mathbf{T}_{\mathbf{1}}$. It gradually decreased $(1.77 \pm 0.46 \%$ o $)$ at $\mathbf{T}_{\mathbf{2}}$ and reached to its lowest values $(1.634 \pm 0.359 \%$ o $)$ at $\mathbf{T}_{\mathbf{3}}$ and $(1.629 \pm 0.386 \%$ o $)$ at $\mathbf{T}_{\mathbf{4}}$. The highest average value of total dissolved solids $(4.24 \pm 1.73 \mathrm{mg} / \mathrm{l})$ was recorded at $\mathbf{T}_{\mathbf{1}}$. It gradually decreased in bonds of $\mathbf{T}_{\mathbf{2}}(3.62 \pm 0.91 \mathrm{mg} / \mathrm{l})$, followed by bonds of $\mathbf{T}_{\mathbf{3}}$ $(3.44 \pm 0.70 \mathrm{mg} / \mathrm{l})$ and reached to its lowest value $(3.32 \pm 0.70 \mathrm{mg} / \mathrm{l})$ in bonds of $\mathbf{T}_{\mathbf{4}}$.

Data in Table (1) showed that, the highest average values of hydrogen ion concentration $(8.39 \pm 0.21 \& 8.39 \pm 0.16)$ were recorded at $\mathbf{T}_{\mathbf{1}}$ and $\mathbf{T}_{\mathbf{2}}$ respectively, while, the lowest average values of $\mathrm{pH}$ were conducted at $\mathbf{T}_{\mathbf{3}}(8.30 \pm 0.19)$ and $\mathbf{T}_{\mathbf{4}}$ $(8.30 \pm 0.21)$ respectively. The average values of dissolved oxygen content ranged between $6.20 \pm 1.14 \mathrm{mg} / \mathrm{l}$ at $\mathbf{T}_{\mathbf{1}}$ to $7.61 \pm 2.47 \mathrm{mg} / \mathrm{l}$ at $\mathbf{T}_{\mathbf{4}}$. The average values of water temperature ranged between $19.46{ }^{\circ} \mathrm{C}$ and $30.73{ }^{\circ} \mathrm{C}$ in all treatments.

Results in Table (1) showed that, the average values of total alkalinity ranged between $281.94 \pm 52.54$ to $312.77 \pm 29.34 \mathrm{mg} / \mathrm{l}$ at $\mathbf{T}_{\mathbf{3}}$ and $\mathbf{T}_{\mathbf{4}}$ respectively. The highest average value of total hardness $(1634.76 \pm 387.09 \mathrm{mg} / \mathrm{l})$ was recorded at $\mathbf{T}_{\mathbf{1}}$. It gradually decreased to $1154.72 \pm 390.36$ and $1117.22 \pm 442.16 \mathrm{mg} / \mathrm{l}$ at $\mathbf{T}_{\mathbf{2}}$ and $\mathbf{T}_{\mathbf{3}}$, and reached to its lowest value $(1096.11 \pm 459.73 \mathrm{mg} / \mathrm{l})$ at $\mathbf{T}_{\mathbf{4}}$. 
Data in Table (1) showed that, the highest average value of total nitrite was $0.09 \pm 0.07 \mathrm{mg} / \mathrm{l}$ at $\mathbf{T}_{\mathbf{1}}$ and the lowest average value was $0.076 \pm 0.064 \mathrm{mg} / \mathrm{l}$ at $\mathbf{T}_{\mathbf{4}}$. The highest average value of total nitrate $(0.36 \pm 0.29 \mathrm{mg} / \mathrm{l})$ was recorded at $\mathbf{T}_{\mathbf{3}}$ and the lowest average value $(0.29 \pm 0.18 \mathrm{mg} / \mathrm{l})$ was recorded at $\mathbf{T}_{\mathbf{2}}$.

Data in Table (1) showed that, the highest average value of Orthophosphate $(0.25 \pm 0.10 \mathrm{mg} / \mathrm{l})$ was recorded at $\mathbf{T}_{\mathbf{3}}$ and the lowest average value $(0.22 \pm 0.11 \mathrm{mg} / \mathrm{l})$ occurred at $\mathbf{T}_{\mathbf{4}}$. The highest average value of Chlorophyll $(232.45 \pm 143.05 \mu \mathrm{g} / \mathrm{l}) \mathrm{was}$ recorded at $\mathbf{T}_{\mathbf{4}}$ and the lowest average value $(174.56 \pm 36.10 \mu \mathrm{g} / \mathrm{l})$ occurred at $\mathbf{T}_{\mathbf{2}}$.

Table 1: Variations of water quality (Mean \pm SD) of Oreochromis niloticus fry, reared in earthen ponds for seven months with different stocking densities and feeding rates

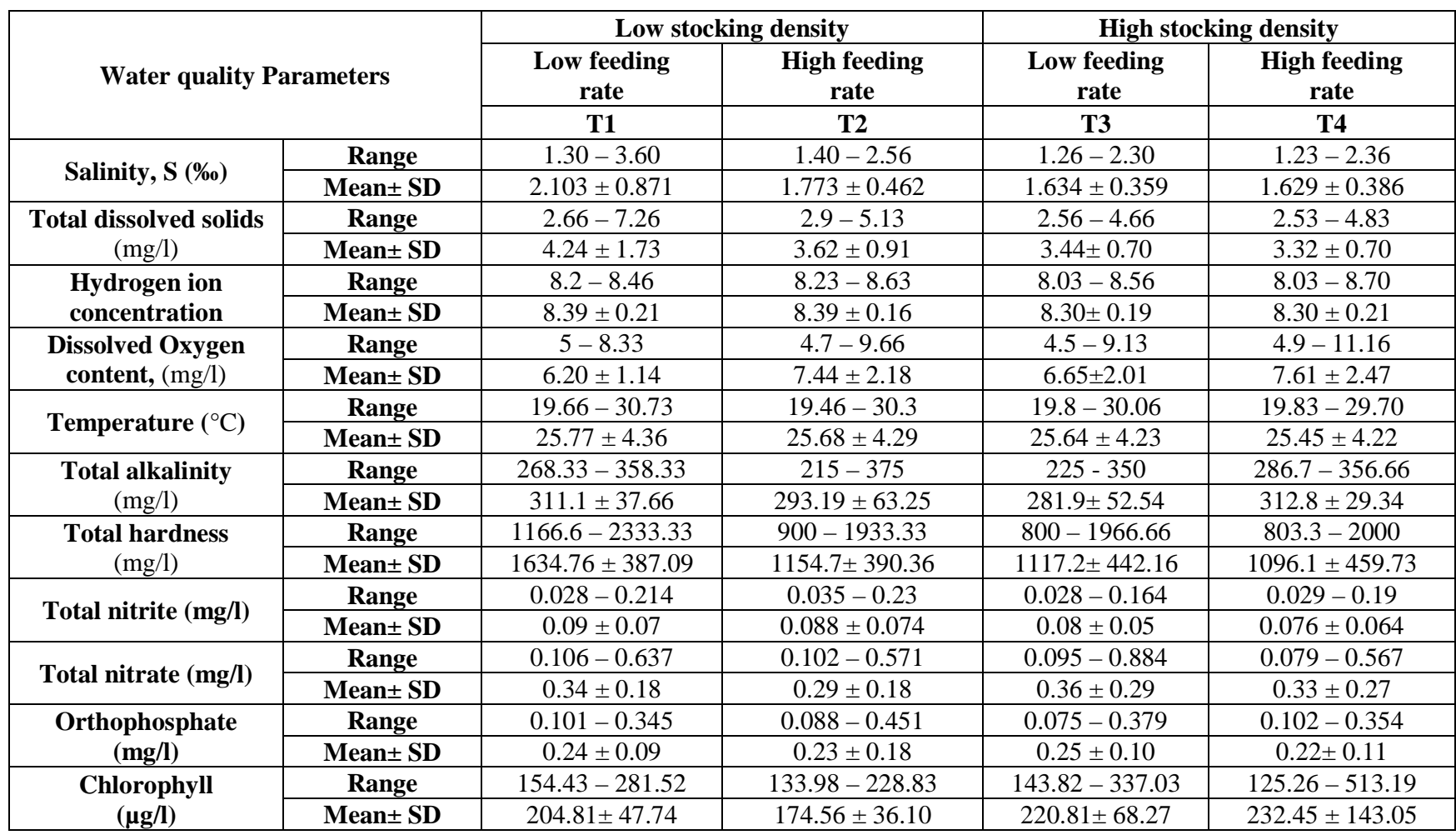

Phytoplankton analyses:

\section{Abundance of phytoplankton:}

The average number of the total phytoplankton was $590.98^{*} 10^{6} \pm 94.394 * 10^{6}$ organism/l. The maximum average number of phytoplankton $\left(222.7 * 10^{6} \pm 37.58 * 10^{6}\right.$ organism/l) was recorded in the ponds of $\mathbf{T}_{\mathbf{4}}$. This average decreased in ponds of $\mathbf{T}_{\mathbf{3}}$ $\left(221.4 * 10^{6} \pm 16.80^{*} 10^{6}\right.$ organism/l), and $\mathbf{T}_{\mathbf{1}}\left(187.0 * 10^{6} \pm 17.4 * 10^{6}\right.$ organism/l), and reached to its minimum value $\left(156.8 * 10^{6} \pm 22.02 * 10^{6}\right.$ organism/l) in ponds of $\mathbf{T}_{2}$. The variations in phytoplankton abundance were generally non-significant between the different experimental treatments (Table 2 and Fig. 1).

Fig. 1: Average phytoplankton abundance $\left(10^{6}\right.$ organism/l) in different treatment ponds during the period of experiment.

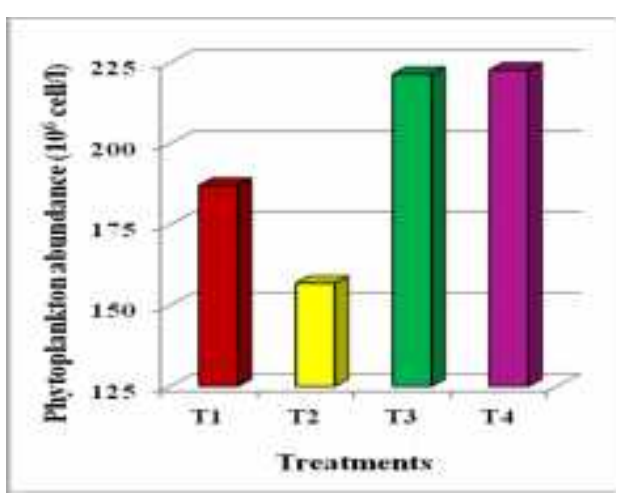


Table 2: Total phytoplankton count $\times 10^{6}$ and abundance of phytoplankton taxa ( $\%$ of total number), in earthen ponds of different treatments, during the experiment period.

\begin{tabular}{|c|c|c|c|c|c|c|c|}
\hline \multirow{2}{*}{ ؛. } & \multirow{2}{*}{\multicolumn{2}{|c|}{ Genus }} & \multicolumn{4}{|c|}{ Treatments } & \multirow[t]{2}{*}{ Whole ponds } \\
\hline & & & $\mathbf{T}_{1}$ & $\mathbf{T}_{2}$ & $\mathbf{T}_{3}$ & $\mathbf{T}_{4}$ & \\
\hline \multirow{16}{*}{ 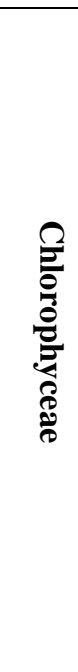 } & \multicolumn{2}{|c|}{ Chlorella } & 4.0 & 3.67 & 5.38 & 3.79 & 4.26 \\
\hline & \multicolumn{2}{|c|}{ Crucigenia } & 3.59 & 3.55 & 3.38 & 3.62 & 3.53 \\
\hline & \multicolumn{2}{|c|}{ Scenedesmus } & 4.62 & 4.41 & 3.64 & 4.05 & 4.14 \\
\hline & \multicolumn{2}{|c|}{ Kirchneriella } & 2.77 & 1.60 & 2.25 & 1.81 & 2.12 \\
\hline & \multicolumn{2}{|c|}{ Pediastrum } & 0.92 & 0.98 & 2.17 & 1.72 & 1.51 \\
\hline & \multicolumn{2}{|c|}{ Closterium } & 2.26 & 1.96 & 2.69 & 2.67 & 2.44 \\
\hline & \multicolumn{2}{|c|}{ Cosmarium } & 3.08 & 0.73 & 1.99 & 0.60 & 1.61 \\
\hline & \multicolumn{2}{|c|}{ Chlamdomonas } & 4.62 & 5.88 & 4.86 & 4.65 & 4.95 \\
\hline & \multicolumn{2}{|c|}{ Staurastrum } & 1.25 & 1.95 & 2.17 & 2.07 & 1.88 \\
\hline & \multicolumn{2}{|c|}{ Tetradroen } & 1.85 & 2.07 & 2.08 & 2.33 & 2.09 \\
\hline & \multicolumn{2}{|c|}{ Protococcus } & 3.90 & 3.92 & 3.56 & 3.28 & 3.63 \\
\hline & \multicolumn{2}{|c|}{ Tetrastrum } & 1.54 & 1.22 & 0.95 & 1.21 & 1.22 \\
\hline & \multicolumn{2}{|c|}{ Schroederia } & 5.75 & 7.04 & 5.77 & 7.07 & 6.38 \\
\hline & \multicolumn{2}{|c|}{ Microspora } & 3.28 & 2.37 & 3.21 & 1.90 & 2.69 \\
\hline & \multirow{2}{*}{$\begin{array}{l}\text { Total } \\
(\%)\end{array}$} & Average & $43.1 \mathrm{~A}$ & $41.5 \mathrm{~A}$ & $44.0 \mathrm{~A}$ & $41.3 \mathrm{~A}$ & \multirow[t]{2}{*}{$42.46 \mathrm{~A}$} \\
\hline & & SD & 5.64 & 4.72 & 2.14 & 6.91 & \\
\hline \multirow{6}{*}{ 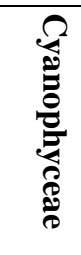 } & \multicolumn{2}{|c|}{ Anabaena } & 4.93 & 1.76 & 1.13 & 1.64 & 2.30 \\
\hline & \multicolumn{2}{|c|}{ Merisomopedia } & 2.36 & 2.94 & 3.64 & 3.53 & 3.17 \\
\hline & \multicolumn{2}{|c|}{ Gleocapsa } & 4.52 & 4.53 & 4.16 & 3.53 & 4.14 \\
\hline & \multicolumn{2}{|c|}{ Microcystes } & 2.46 & 2.33 & 2.95 & 1.81 & 2.39 \\
\hline & & Average & 14.3 B & $11.8 \mathrm{~B}$ & $11.8 \mathrm{~B}$ & 10.7 B & $12.00 \mathrm{~B}$ \\
\hline & $(\%)$ & SD & 1.47 & 2.90 & 0.90 & 1.75 & \\
\hline & Cyclote & & 6.77 & 7.06 & 8.98 & 11.81 & 8.87 \\
\hline อี. & Syned & & 2.87 & 1.10 & 2.95 & 1.90 & 2.27 \\
\hline$\overline{\bar{a}}$ & Tabella & & 0.51 & 0.73 & 0.35 & 0.43 & 0.49 \\
\hline 0 & Diaton & & 0.10 & 0.12 & 0.00 & 0.09 & 0.07 \\
\hline $\bar{z}$ & Total & Average & 10.2 B & $9.0 \mathrm{~B}$ & $12.2 \mathrm{~B}$ & 13,6 B & $11.70 \mathrm{~B}$ \\
\hline है & & SD & 4.66 & 0.13 & 1.66 & 6.08 & \\
\hline & Eugle & & 15.9 & 22.28 & 16.39 & 18.66 & 17.90 \\
\hline â & Phact & & 8.83 & 9.18 & 6.85 & 6.64 & 7.72 \\
\hline E: & Trachelon & nas & 5.23 & 3.67 & 4.77 & 6.99 & 5.29 \\
\hline$\frac{0}{0}$ & Lepocin & & 2.87 & 2.94 & 3.73 & 2.19 & 2.93 \\
\hline$\frac{E}{2}$ & Total & Average & 32.4 & $37.7 \mathrm{C}$ & $31.9 \mathrm{C}$ & 34.4 C & $33.85 \mathrm{C}$ \\
\hline है & $(\%)$ & SD & $7.69 \mathrm{C}$ & 4.69 & 3.99 & 2.78 & \\
\hline Tot: & nnism*10 $6 /$ l & Average & $\begin{array}{c}187.0 \\
\text { NS }\end{array}$ & $\begin{array}{c}156.8 \\
\text { NS }\end{array}$ & $\begin{array}{c}221.4 \\
\text { NS }\end{array}$ & $\begin{array}{c}222.7 \\
\text { NS }\end{array}$ & 590.98 \\
\hline & & SD & 17.4 & 22.02 & 16.80 & 37.58 & 94.394 \\
\hline
\end{tabular}

Averages that do not share a letter, are significantly varied; NS: non-significant, SD: standard deviation.

Four divisions of phytoplankton were recorded in the experimental fish ponds, which are: Chlorophyceae, Cyanophyceae, Bacillorophyceae and Euglinophyceae. The most abundant division in all experimental fish ponds was Chlorophyceae (with whole average of $42.46 \%$ of the total number of phytoplankton specimens); followed by Euglinophyceae, with whole average of $33.85 \%$ of the total number of phytoplankton specimens. The variations in abundance were statistically significant between different phytoplankton divisions (Table 2 and Fig. 2). 


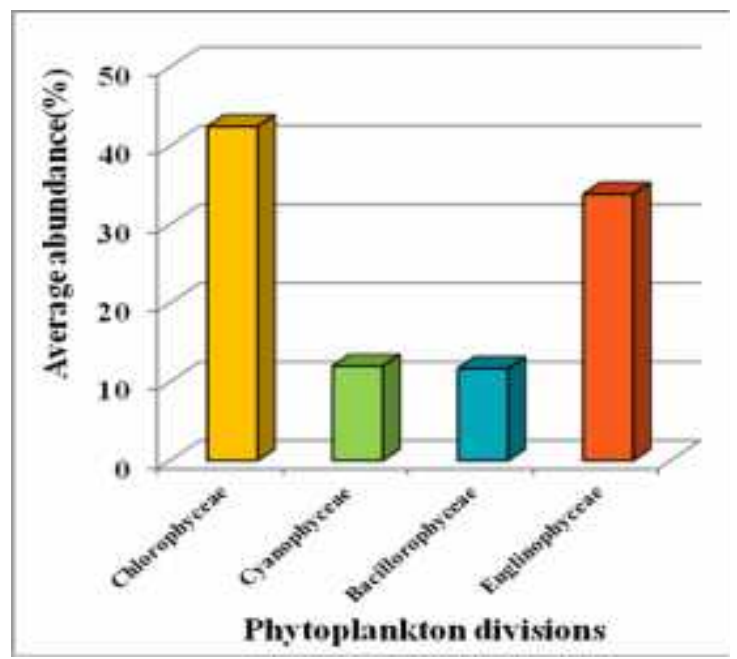

Fig. 2: Average abundance ( $\%$ of the total phytoplankton number of whole experimental ponds) of different phytoplankton divisions, during the period of experiment.

Data in Table (2) showed that Schroederia and Chlamdomonas were the most abundant taxa of Chlorophyceae, representing $6.38 \%$ and $4.95 \%$ of the total number of phytoplankton specimens, respectively. Tetrastrum and Cosmarium were the minor component of Chlorophyceae.

The highest average value of Chlorophyceae abundance ( $\%$ of the total number of phytoplankton specimens in the treatment ponds) was recorded in $\mathbf{T}_{\mathbf{3}}(44.0 \pm 2.14$ $\%)$, followed by $\mathbf{T}_{\mathbf{1}}(43.1 \pm 5.64 \%)$ and reached to its lowest values $(41.5 \pm 4.72 \%$ and $41.3 \pm 6.91 \%$ ) in $\mathbf{T}_{\mathbf{2}}$ and $\mathbf{T}_{\mathbf{4}}$, respectively (Table 2 and Fig. 3).

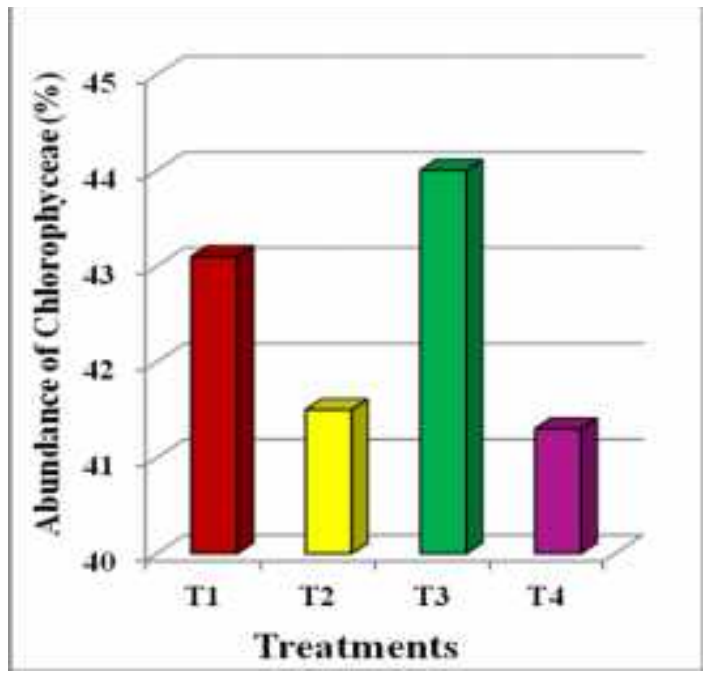

Fig. 3: Average Chlorophyceae abundance (as $\%$ of the total number of phytoplankton in each treatment) during the period of experiment

Data in Table (2) showed that Gleocapsa was the most abundant component of Cyanophyceae, representing $4.14 \%$ of the total number of phytoplankton specimens. Anabaena was the minor component of Cyanophyceae. The maximum average value of Cyanophyceae abundance ( $\%$ of the total number of phytoplankton specimens in the treatment ponds) was recorded in $\mathbf{T}_{\mathbf{1}}(14.3 \pm 1.47 \%)$ and the minimum average $(10.7 \pm 1.75 \%)$ occurred in $\mathbf{T}_{4}$.

Data in Table (2) showed that Cyclotella was the most dominant taxa of Bacillorophyceae, representing $8.87 \%$ of the total number of phytoplankton 
specimens. Diatoma was the minor taxa of Bacillorophyceae $(0.07 \%)$. The highest average value in Bacillorophyceae abundance (\% of the total number of phytoplankton specimens in the treatment ponds) was recorded in $\mathbf{T}_{\mathbf{4}}(13.6 \pm 6.08 \%)$. This value gradually decreased to $12.2 \pm 1.66 \%$ and $10.20 \pm 4.66 \%$ in $\mathbf{T}_{\mathbf{3}}$ and $\mathbf{T}_{\mathbf{1}}$ respectively. The lowest value $(9 \pm 0.13 \%)$ was recorded in $\mathbf{T}_{2}$.

Euglena was the main taxa, representing $17.9 \%$ of the total number of phytoplankton specimens. Lepocinclis was the minor one of Euglinophyceae (2.93 $\%$ ).The highest average value of Euglinophyceae abundance (\% of the total number of phytoplankton specimens in the treatment ponds) was recorded in $\mathbf{T}_{\mathbf{2}}(37.7 \pm 4.69$ $\%$ ). It gradually decreased to $34.4 \pm 2.78 \%$ and $32.4 \pm 7.69 \% \mathbf{i n}_{\mathbf{4}}$, and $\mathbf{T}_{\mathbf{1}}$, respectively. It reached to its minimum abundant value $(31.9 \pm 3.99 \%)$ in $\mathbf{T}_{\mathbf{3}}$ (Table 2 and Fig. 4).

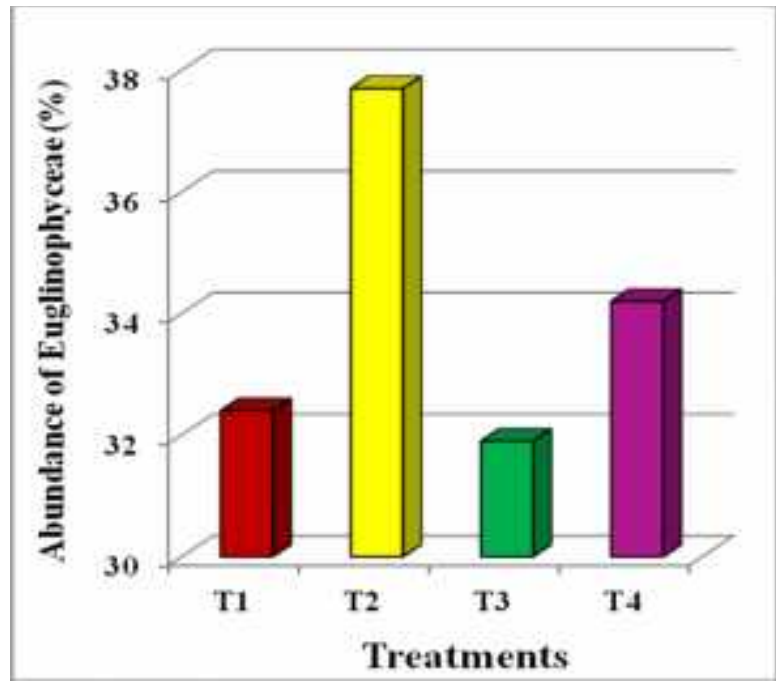

Fig. 4: Average Euglinophyceae abundance (as $\%$ of the total number of phytoplankton in each treatment) during the period of experiment

Monthly variation in abundance of phytoplankton:

The highest average value in monthly abundance of all phytoplankton groups $\left(37.1 * 10^{6} \pm 27.41 * 10^{6}\right.$ organism/l) was recorded in $\mathbf{T}_{\mathbf{4}}$. It gradually decreased to $36.9 * 10^{6} \pm 18.33 * 10^{6}$ organism/l and $31.2^{*} 10^{6} \pm 16.47 * 10^{6}$ organism/l in $\mathbf{T}_{\mathbf{3}}$ and $\mathbf{T}_{\mathbf{1}}$, respectively. It reached to its lowest value $\left(26.1 * 10^{6} \pm 23.73 * 10^{6}\right.$ organism/l) in $\mathbf{T}_{\mathbf{2}}$. The phytoplankton abundance was greatly varied in each treatment ponds during different months of the experiment. Generally, it reached the highest averages during the period of September-November in all treatments, and the lowest averages were recorded during June (Table 3 and Fig. 5).

The highest average value in monthly abundance of Chlorophyceae $(41.8 \pm 15.82$ $\%$ ) was recorded in $\mathbf{T}_{\mathbf{1}}$. It gradually decreased $(39.1 \pm 17.27 \%)$ in $\mathbf{T}_{\mathbf{3}}$, followed by $\mathbf{T}_{\mathbf{4}}$ $(35.9 \pm 17.65 \%)$ and reached to its lowest value of $32.7 \pm 26.20 \%$ in $\mathbf{T}_{2}$. Monthly variation in abundance of phytoplankton groups showed that Chlorophyceae was more abundant in September and less abundant in July. It was entirely absent in $\mathbf{T}_{\mathbf{2}}$ at July and August (Table 3).

Results showed that, the maximum average value in monthly abundance of Cyanophyta $(16.5 \pm 10.76 \%)$ was recorded in $\mathrm{T}_{1}$ and the minimum value $(7.4 \pm 5.98 \%)$ occurred in $\mathbf{T}_{\mathbf{4}}$. Monthly variation in abundance of phytoplankton groups showed that Cyanophyceae was more abundant in July and less abundant in June. It was entirely absent in $\mathbf{T}_{\mathbf{2}}$ at June and July and in $\mathbf{T}_{\mathbf{4}}$ at June and August (Table 3). 


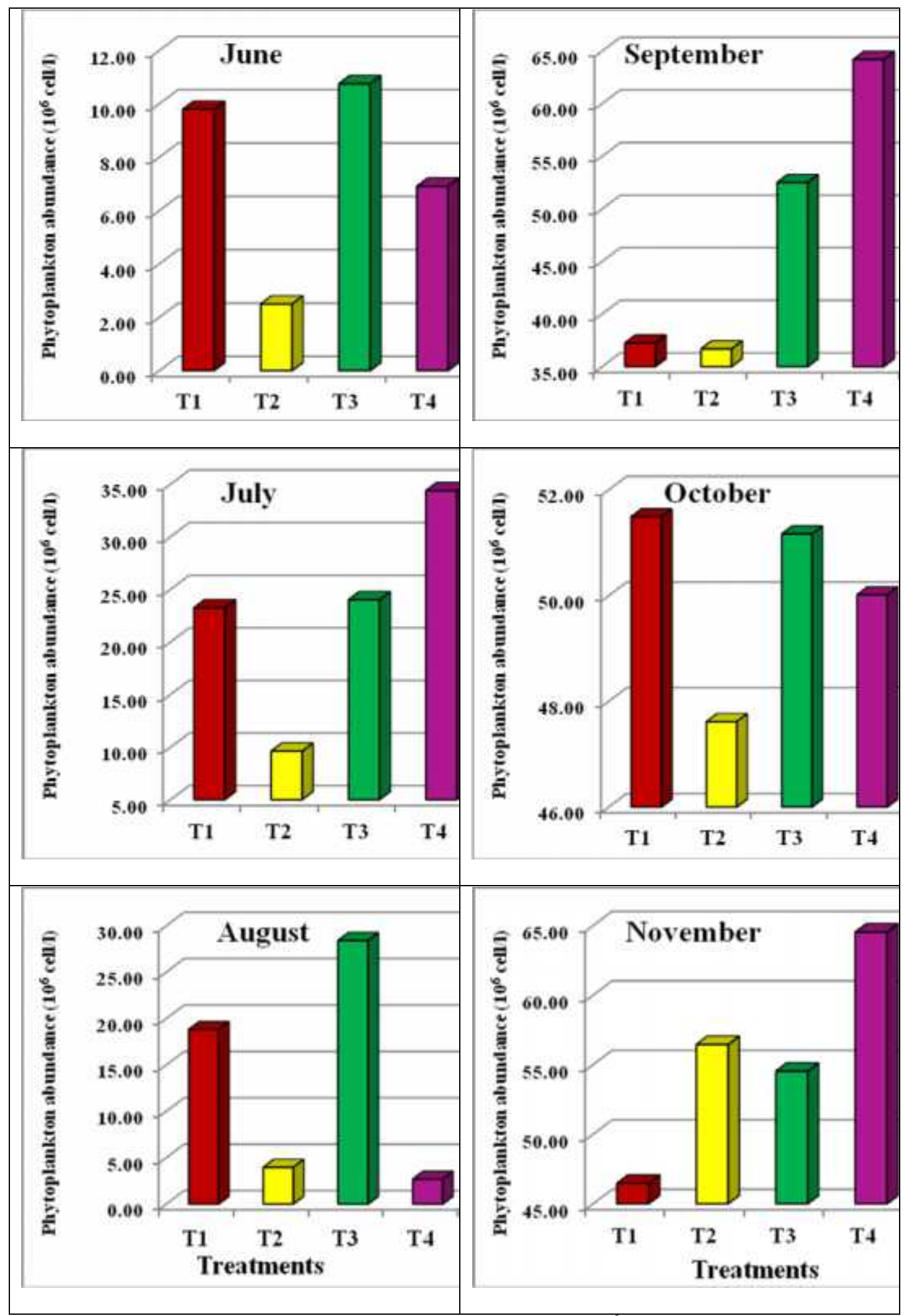

Fig. 5: Monthly variation in the average phytoplankton abundance $\left(10^{6}\right.$ organism/l) in each treatment, during the period of experiment 
Table 3: Monthly variation in total phytoplankton count $\times 10^{6}$ and abundance of phytoplankton groups (\% of total number), in earthen ponds of different treatments

\begin{tabular}{|c|c|c|c|c|c|c|}
\hline \multirow{2}{*}{ 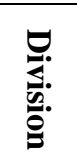 } & \multirow{2}{*}{\multicolumn{2}{|c|}{ Month }} & \multicolumn{4}{|c|}{ Treatments } \\
\hline & & & $\mathbf{T}_{1}$ & $\mathbf{T}_{2}$ & $\mathbf{T}_{3}$ & $\mathbf{T}_{\mathbf{4}}$ \\
\hline \multirow{7}{*}{ 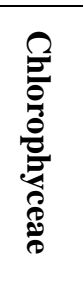 } & \multicolumn{2}{|l|}{ June } & 50.98 & 61.54 & 25.00 & 30.56 \\
\hline & \multicolumn{2}{|l|}{ July } & 9.92 & 0.00 & 10.40 & 4.47 \\
\hline & \multicolumn{2}{|l|}{ August } & 43.88 & 0.00 & 51.35 & 35.71 \\
\hline & \multicolumn{2}{|c|}{ September } & 50.00 & 43.82 & 51.92 & 55.32 \\
\hline & \multicolumn{2}{|l|}{ October } & 48.17 & 47.58 & 47.84 & 47.22 \\
\hline & \multicolumn{2}{|c|}{ November } & 47.94 & 43.54 & 47.89 & 41.95 \\
\hline & \multicolumn{2}{|c|}{ Total $($ average \pm SD) } & $41.8 \pm 15.82$ & $32.7 \pm 26.20$ & $39.1 \pm 17.27$ & $35.9 \pm 17.65$ \\
\hline \multirow{7}{*}{ 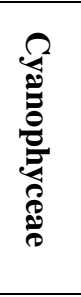 } & \multicolumn{2}{|c|}{ June } & 25.49 & 0.00 & 8.93 & 0.00 \\
\hline & \multicolumn{2}{|l|}{ July } & 33.88 & 0.00 & 8.80 & 10.61 \\
\hline & \multicolumn{2}{|c|}{ August } & 6.12 & 33.89 & 9.46 & 0.00 \\
\hline & \multicolumn{2}{|l|}{ September } & 10.31 & 13.79 & 11.70 & 10.47 \\
\hline & \multicolumn{2}{|c|}{ October } & 11.93 & 10.89 & 13.13 & 14.20 \\
\hline & \multicolumn{2}{|c|}{ November } & 11.16 & 11.56 & 14.08 & 9.22 \\
\hline & \multicolumn{2}{|c|}{ Total (average \pm SD) } & $16.5 \pm 10.76$ & $11.7 \pm 12.42$ & $11.0 \pm 2.28$ & $7.4 \pm 5.98$ \\
\hline \multirow{7}{*}{ 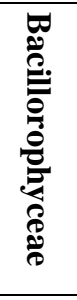 } & \multicolumn{2}{|c|}{ June } & 23.53 & 0.00 & 39.29 & 61.11 \\
\hline & \multicolumn{2}{|l|}{ July } & 11.57 & 28.00 & 27.20 & 46.93 \\
\hline & \multicolumn{2}{|c|}{ August } & 29.59 & 66.11 & 27.03 & 64.29 \\
\hline & \multicolumn{2}{|c|}{ September } & 5.67 & 6.28 & 5.67 & 6.28 \\
\hline & \multicolumn{2}{|c|}{ October } & 6.71 & 6.05 & 4.50 & 4.61 \\
\hline & \multicolumn{2}{|l|}{ November } & 6.61 & 6.46 & 6.34 & 5.06 \\
\hline & Total (av & age \pm SD) & $13.9 \pm 10.17$ & $18.8 \pm 25.09$ & $18.3 \pm 14.76$ & $31.4 \pm 29.15$ \\
\hline & June & & 0.00 & 38.46 & 26.79 & 61.11 \\
\hline वี & July & & 44.63 & 72.00 & 53.60 & 46.93 \\
\hline $\bar{\Xi}$ & August & & 20.41 & 0.00 & 12.16 & 64.29 \\
\hline 을 & Septembe & & 34.02 & 36.11 & 30.71 & 6.28 \\
\hline క్ & October & & 33.18 & 35.48 & 34.52 & 4.61 \\
\hline है & Novembel & & 34.30 & 38.44 & 31.69 & 5.06 \\
\hline & Total (av & age \pm SD) & $27.8 \pm 15.62$ & $36.8 \pm 22.81$ & $31.6 \pm 13.37$ & $25.3 \pm 17.39$ \\
\hline & June & & 9.79 & 2.50 & 10.75 & 6.91 \\
\hline & July & & 23.23 & 9.60 & 24.00 & 34.37 \\
\hline$\widehat{\varrho}$ & August & & 18.82 & 3.96 & 28.42 & 2.69 \\
\hline 严 & Septembe & & 37.25 & 36.69 & 52.51 & 64.21 \\
\hline . & October & & 51.49 & 47.62 & 51.17 & 50.02 \\
\hline * & November & & 46.47 & 56.45 & 54.53 & 64.54 \\
\hline 요읒 & Total & Average & 187.0 & 156.8 & 221.4 & 222.7 \\
\hline $\overrightarrow{0}$ & & SD & $\pm \mathbf{1 7 . 4 0}$ & \pm 22.02 & \pm 16.80 & \pm 37.58 \\
\hline & Monthly & Average & 31.2 & 26.1 & 36.9 & 37.1 \\
\hline & & SD & \pm 16.47 & \pm 23.73 & \pm 18.33 & \pm 27.41 \\
\hline
\end{tabular}

Data in Table (3) showed that, the highest average value in monthly abundance of Bacillorophyceae $(31.4 \pm 29.15 \%)$ was recorded in $\mathbf{T}_{4}$ and the lowest value $(13.9 \pm 10.17 \%)$ occurred in $\mathbf{T}_{\mathbf{1}}$. Monthly variation in abundance of phytoplankton groups showed that Bacillorophyceae was more abundant in August and less abundant in September and October. It was entirely absent in $\mathbf{T}_{\mathbf{2}}$ at June.

Results in Table (3) showed that, the maximum average value in monthly abundance of Euglinophyceae $(36.8 \pm 22.81 \%)$ was recorded in $\mathbf{T}_{\mathbf{2}}$. It gradually decreased to $31.6 \pm 13.37 \%$ in $\mathbf{T}_{3}$, followed by $25.3 \pm 17.39 \%$ in $\mathbf{T}_{4}$ and reached to its minimum value $(27.8 \pm 15.62 \%)$ in $\mathbf{T}_{\mathbf{1}}$. Monthly variation in abundance of 
phytoplankton groups showed that Euglinophyceae was more abundant in July and less abundant in August. It was entirely absent in $\mathbf{T}_{\mathbf{1}}$ at June and in $\mathbf{T}_{\mathbf{2}}$ at August.

\section{DISCUSSION}

The aquaculture production is directly affected by aquaculture ecosystems. Nutrient availability, water quality, soil grain size analysis, and plankton (community, productivity and nutritional composition) are the main ecosystem components affecting the cultured fish in earthen ponds (Ssanyu et al., 2011).

In the present study, the lowest average values of salinity and total dissolved solids (1.629 $\pm 0.386 \%$ and $3.32 \pm 0.70 \mathrm{mg} / \mathrm{l}$, respectively) were recorded at $\mathbf{T}_{\mathbf{4}}$ (high stocking density with high feeding rate). While, the highest average values of salinity and total dissolved solids $(2.103 \pm 0.871 \%$ ond $4.24 \pm 1.73 \mathrm{mg} / \mathrm{l}$, respectively) were recorded at $\mathbf{T}_{\mathbf{1}}$ (low stocking density with low feeding rate). These results were in the optimum range in salinity needed for cultured O. niloticus (El-Sayed, 2006 and Ashour et al., 2018).

In the present study, the lowest average value of hydrogen ion concentration (8.30) was recorded in $\mathbf{T}_{\mathbf{3}}$ and $\mathbf{T}_{\mathbf{4}}$ (high stocking density of $8 \mathrm{fish} / \mathrm{m}^{3}$ ) and its highest average value (8.39) was recorded in $\mathbf{T}_{\mathbf{1}}$ and $\mathbf{T}_{\mathbf{2}}$ (low stocking density of $6 \mathrm{fish} / \mathrm{m}^{3}$ ). Boyd (1982) reported that the phytoplankton consumed $\mathrm{CO}_{2}$ and decrease of $\mathrm{pH}$ with highly stocking density. The tolerance of $\mathrm{pH}$ ranged from 5 to 11, but optimal results can usually be obtained only between $\mathrm{pH} 6$ and 9 .

In the present study, the lowest average values of dissolved oxygen concentration were recorded in $\mathbf{T}_{1}$ and $\mathbf{T}_{3}$ (low feeding rate of $2.5 \%$ ), being $6.20 \pm$ $1.14 \mathrm{mg} / \mathrm{l} \& 6.65 \pm 2.01 \mathrm{mg} / \mathrm{l}$, respectively. The highest average values of dissolved oxygen concentration were recorded at $\mathbf{T}_{\mathbf{2}}$ and $\mathbf{T}_{\mathbf{4}}$ (high feeding rate of $3.5 \%$ ), being7.44 $\pm 2.18 \mathrm{mg} / \mathrm{l} \& 7.61 \pm 2.47 \mathrm{mg} / \mathrm{l}$, respectively. This result more or less similar to the result was obtained by Sultana et al. (2017). The fluctuation in oxygen concentrations might be attributed to photosynthetic activity and the variation of oxygen consumption by fish and other organisms (Afia et al., 2018). Abdel-Tawwab et al. (2007) found that the concentration of dissolved oxygen was positively correlated with feeding rates. Generally, it could be noted that the average dissolved oxygen at different treatments lies within the permissible limits (Abdel-Tawwab et al., 2014).

The variation in water temperature influences the solubility of gases, $\mathrm{pH}$, conductivity and phytoplankton distribution. In the present study, the average value of water temperature ranged between $19-30^{\circ} \mathrm{C}$ in all treatments. This result is matching with Sifa et al. (2002). They mentioned that Tilapias are thermophilic fish and known to tolerate a wide range of water temperatures. The temperature range for the normal development, reproduction and growth was fluctuated between 20 and $35^{\circ} \mathrm{C}$, depending on fish species, with an optimum range of about $25-30^{\circ} \mathrm{C}$.

The highest average value of total hardness (1634.76 $\pm 387.09 \mathrm{mgll})$ was recorded at $\mathbf{T}_{\mathbf{1}}$ (low stocking density and low feeding rate) and the lowest value $\left(1096.11 \pm 459.73 \mathrm{mgl}\right.$ ) was recorded at $\mathbf{T}_{\mathbf{4}}$ (high stocking density and high feeding rate). This mainly due to increase in photosynthesis activity in $\mathbf{T}_{\mathbf{4}}$, which leads to the consumption of carbon dioxide $\left(\mathrm{Co}_{2}\right)$ and hydrolysis of bicarbonate $\left(\mathrm{HCo}_{3}\right)$ (Boyd, 1990). On the other hand, Pote et al. (1990) mentioned that the increasing the ratio of hardness to alkalinity, $\mathrm{pH}$ fluctuation would be moderate and the maximum daily $\mathrm{pH}$ would be reduced. 
High nitrate concentration directly affected plankton densities. In the present study, the average value of total nitrate $(\mathrm{mg} / \mathrm{l})$ was higher in $\mathbf{T}_{\mathbf{3}}$ and $\mathbf{T}_{\mathbf{4}}$ (high stocking density) than that in $\mathbf{T}_{\mathbf{1}}$ and $\mathbf{T}_{\mathbf{2}}$ (low stocking density). It may be attributed to high densities of phytoplankton in $\mathbf{T}_{\mathbf{3}}$ and $\mathbf{T}_{\mathbf{4}}$. This might be due to the fact that increase in nitrogen inflow stimulates the plankton community (Mischke and Zimba, 2004). On the other hand, the values of $\mathrm{NO}_{3}$ were fluctuated from 0.12 to 0.78 in irrigation water of El- Salam and El- Mahmoudia canals (Ashour et al., 2018).

In the present study, the highest average value of Orthophosphate was recorded at $\mathbf{T}_{\mathbf{3}}$ and $\mathbf{T}_{\mathbf{1}}$ (low feeding rate) and the lowest occurred at $\mathbf{T}_{\mathbf{4}}$ and $\mathbf{T}_{\mathbf{2}}$ (high feeding rate). The lowest of Orthophosphate value in $\mathbf{T}_{\mathbf{4}}$, may be due to increase of phytoplankton in these treatments which uses in photosynthesis. This result was disagreement the results of El-Dahhar et al. (2006) who found that the total phosphorus level was increased in direct proportion with feeding rate. As well as Abdel-Tawwab et al. (2007) reported that phosphate concentration also increased significantly with the increase in feeding rate of Tilapia, silver carp and common carp under poly-culture systems.

Ssanyu et al. (2011) concluded that the relative status of plankton gives an indicator of water quality parameter and the possible success or failure of the aquaculture system of $O$. niloticus. Quantification of phytoplankton as a primary production in terms of chlorophyll- $a$ is alternative, easy and quick to measure phytoplankton biomass in aquaculture (Ashour et al., 2018). In the present study, the highest average values $(232.45 \pm 143.05 \mu \mathrm{g} / \mathrm{l}$ and $220.81 \pm 68.27 \mu \mathrm{g} / \mathrm{l})$ of Chlorophyll a were recorded with high stocking density at $\mathbf{T}_{\mathbf{4}}$ and $\mathbf{T}_{\mathbf{3}}$ respectively, while the lowest values $(204.81 \pm 47.74$ and $174.56 \pm 36.10 \mu \mathrm{g} \backslash \mathrm{l})$ were recorded with low stocking density at $\mathbf{T}_{1}$ and $\mathbf{T}_{2}$ respectively. This result may be due to the abundance of phytoplankton in these treatments. Chlorophyll $a$ was increased with increasing in stocking density, may be due to uses fish feces in photosynthesis. In contrast, this result is differing with the result detected by Teichert-Coddington (1996) who noticed that the total nitrogen and chlorophyll $a$ decreased linearly as rate of stocked tilapia increased, because of grazing by tilapia on phytoplankton.

Concerning the stocking density variations, the maximum values of all physicochemical parameters of water were observed with low stocking density, except dissolved oxygen and nitrogenous compounds with high stocking density. This could be attributed to increase of phytoplankton abundance in these treatments. Tilapia ecosystems and productivities are indirectly affected by the changes of water quality conditions, which can regulate the plankton productivity, biochemical composition and community in such tilapia earthen ponds. These conditions fundamentally change due to the availability of nutrient concentrations (El-Otify, 2015).

Plankton was required as the first food for many cultured fish. They are valuable natural sources of protein, amino acids, lipids, fatty acids, minerals and enzymes required for effective growth of fish (Ajah, 2017). In the present study, the high concentrations of nutrients coinciding with higher abundance of phytoplankton (organism/l) in earthen ponds of $\mathbf{T}_{\mathbf{4}}$ and $\mathbf{T}_{\mathbf{3}}$ (high stocking density). Mou et al. (2018) mentioned that the phytoplankton abundance was higher with low stocking density of fry and fingerlings of Mystus vittatus. It seems likely that in the ponds where stocking density is high, consumption of plankton by fishes is also high. These results were in agreement with Khattaby et al., 2010, they found that Nile Tilapia reared in agriculture daring water grow up higher than Nile Tilapia reared in fresh water, because agricultural drainage water contains high concentration of natural food 
(phytoplankton). The increase of plankton abundance can significantly increase fish production in ponds (Geiger and Parker, 1985).

In the present study, Chlorophyta is more abundant in September and less abundant in July. The most abundant taxa captured of chlorophyceae were Schroederia and Chlamdomonas, which peaked during September. Cyanophyta is more abundant in July and less abundant in June. The most abundant taxa among cyanophyceae were Gleocapsa, which peaked during July. Bacillorophyta is more abundant in August and less abundant in September. The most abundant taxa among Bacillariophyceae were Cyclotella, which peaked during August Euglinophyta is more abundant in July and less abundant in August. The most abundant taxa among the Euglenophyceae were Euglena which peaked during July.

Schroeder (1987) correlated the isotopic carbon ratios of various microbial species present in fertilized ponds with the fish harvested from the pond. The bacterial component is the primary nutrient source for Tilapia cultured in a fertilized pond and cyanobacteria (blue-green algae) provide the second important nutrient source.

\section{CONCLUSION}

The highest stocking density $\left(8 \mathrm{fish} / \mathrm{m}^{3}\right)$ with low feeding rate $(2.5 \%)$ was positively correlated with best water quality and high abundance of phytoplankton in earthen ponds of Oreochromis niloticus.

\section{REFERENCES}

Abdel-Naby, A.S.; Samir, F.; Abdel Razek, N. and Khattaby, A.A. (2017): effect of aquaviance product as dietary supplementation to improve growth performance, feed intake, innate immunity and antioxidant activity for Nile Tilapia, Oreochromis niloticus. Abbassa Int. J. Aqua., 10 (1): 114 - 138.

Abdel-Tawwab, M.; Abdel-Ghany, A.E. and Ahmad, M.H. (2007): Effect of feed supplementation on water properties, phytoplankton community structure and the growth of Nile Tilapia, Oreochromis niloticus (L.), common carp, Cyprinus carpio L., and silver carp, Hypophthalmichthys molitrix V. polycultured in fertilized earthen ponds. J. Applied. Aquaculture, 19(1): 1-24.

Abdel-Tawwab, M.; Hagras, A.E.; El-Baghdady, H.A. and Monier, M.N. (2014): Dissolved oxygen level and stocking density effects on growth, feed utilization, physiology, and innate immunity of Nile Tilapia, Oreochromis niloticus, Journal of Applied Aquaculture, 26 (4): 340 - 355.

Afia, O.E.; David, G.S. and Effiong, I.B. (2018): Comparative effect of different stocking densities of heteroclarias on plankton abundance in tarpaulin tanks. Journal of Aquatic Science and Marine Biology., 1 (2): 5-12.

Ajah, P.O. (2017): Effect of intensifying stocking densities and proper feed management techniques on production of Clarias gariepinus (Burchell, 1822) in earthen ponds in Nigeria. International Journal of Engineering Science Invention., 6 (6): 65-70.

APHA (American Public Health and Association) (1992): Standard Methods of the Examination of Water and Wastewater. $18^{\text {th }}$ ed. Washington D.C., Pp: 1015.

Ashour, M.; Abo-Taleb, H.A.; Abou-Mahmoud M.M. and El-Feky, M.M.M. (2018): Effect of the integration between plankton natural productivity and environmental assessment of irrigation water, El-Mahmoudia Canal, on 
aquaculture potential of Oreochromis niloticus. Turkish Journal of Fisheries and Aquatic Sciences., 18: 1163-1175.

Azab, A.M.; Shoman, H.M.; Abd Al-Hakim, N.F. and Mostafa, M.G. (2005): Effect of diet processing and storage on growth and production of the Nile Tilapia, Oreochromis niloticus. African J. Biol. sci., 1(1): 89 - 99.

Bellinger, E.G. and Sigee, D.C. (2010): Freshwater Algae Identification and Use as Bioindicators. Wiley Blackwell.

Boyd, C.E. (1982): Water Quality Management for Pond Fish Culture. Elsevier, Amsterdam.

Boyd, C.E. (1990): Water Quality in Ponds for Aquaculture. Alabama Agriculture Experiment Station, Auburn Univ., Alabama, USA.,Pp: 462.

Boyd, C.E. \& Tucker, C.S. (1992): Water Quality and Pond Soil Analysis for Aquaculture. Alabama Agricultural Experimental Station. Auburn. Uni., Pp: 183.

El-Dahhar, A.A.; Moustafa Y.T.; Salama, M.E.A. and Dawah, A.M. (2006): Effect of fertilization on production of Nile Tilapia in earthen ponds I, Evaluation of untraditional organic fertilizer in earthen pond. Journal of the Arabian Aquaculture Society., 1(2): 91-110.

El-Otify, A.M. (2015): Evaluation of the physicochemical and chlorophyll-a conditions of a subtropical aquaculture in Lake Nasser area, Egypt. Beni-Suef University Journal of Basic and Applied Sciences., 4(4): 327-337.

El-Sayed, A.M. (2006): Tilapia Culture. Oxfordshire, CABI Publishing., Pp: 277.

Fairchild, E.A. and Howell, W.H. (2001): Optimal stocking density for juvenile winter flounder, Seudopleuronectes americanus. Journal of the World Aquaculture Society., 32: 300-308.

F.T.U. (Feed Technology Update) (2007): Insects offer a promising solution to the protein bottle neck, 2 (6): $1-37$.

GAFRD (General Authority for Fish Resources and Development) (2016): Fishery Statistic. Egyptian Ministry of Aquaculture., Pp: 118.

Geiger, J.G. \& Parker, N.C. (1985): Survey of striped bass hatchery management in the southeastern United States. Prog. Fish- cult., 47:1-13.

Gomes, L.C.; Baldisserotto, BandSenhorinl, J.A. (2000): Effect of density on water quality, survival and growth of larvae of the matrinxa, Bryconcephalus (Characidae), in ponds. Aquaculture., 183: 73-81.

Holm, S. (1979): "A simple sequentially rejective multiple test procedure". Scandinavian Journal of Statistics., 6 (2): 65-70.

Houde, E.D. (1977): Food concentration and stocking density effects on survival and growth of laboratory-reared larvae of Bay Anchovy, Anchoa mitchilli and Lined sole, Achirus lineatus. Marine Biology., 43: 333 - 341.

Khattaby, A.A.; Abbas, F.E.; Soltan, M.A. and El-Sayaad, G.A. (2010): Effect of using different water sources on the growth performance of mono-sexed Nile Tilapia, Oreochromis niloticus reared in earthen ponds. Abbassa Int. J. Aqua. Special Issue (The Third Scientific Conference Al-Azhar University, Cairo 1718 October, 2010., P. 129-142.

Kheir, M.T. \& Mohamed, R.A. (2001): Growth of Oreochromis niloticus (L., 1757) and Sarotherodon galilaeus. (Art., 1757) ralsed on an artificial feed at different feeding rates. J. Egypt. Ger. Soc. Zool., 36(B): 13-25.

Luz, R.K. \& Zanibonifilho, E. (2002): Larvicultura do mandiamarelo Pimelodusmaculatus Lacépède, 1803 (Siluriformes: Pimelodidae) 
emdiferentesdensidades de estocagemnosprimeirosdias de vida. Revista Brasileira de Zootecnia., 31: 560 - 565.

Mischke, C.C. \& Zimba, P.V. (2004): Plankton community responses in earthen channel catfish nursery ponds under various fertilization regimes. Aquaculture, 233: 219-235.

Mou, M.H.; Hasan, K.R. and Ahamed, S. (2018): Comparative efficacy of stocking density on growth and survival of fry of Mystus vittatus in nursery ponds. International Journal of Fisheries and Aquatic Research., 3 (1): 22-26.

Pote, J.W., Cathcart, T.P. and Deliman, P.N., (1990): Control of pH in aquaculture ponds. Aquaculture Engineering., 9: 175-186.

Samir, F.; Abd El-Naby, A.S.; Khattaby, A.A. and Awad, S.M.M. (2017): Improvement of growth rate, feed utilization, body composition and immune response of Nile Tilapia (Oreochromis niloticus) by supplementation of nucleotide in diets. International conference (central Laboratory For Aquaculture Research in Cooperation with World fish), Cairo, Egypt., 1st International Conference (Central Laboratory For Aquaculture Research In Cooperation with World fish (Cairo, Egypt, 20-22 November, 2017), 62 - 88.

Schroeder, G.L. (1987): Carbon pathways in aquatic detrital systems. In: Detritus and Microbial Ecology in Aquaculture, ICLARM Conference Proceedings 13. Moriarty, D.J.W. and Pullin, R.S.V. (eds.). Intemational Center for Living Aquatic Resources Management, Manila, Philippines, P. 217-236.

Sifa, L.; Chenhong, L.; Dey, M.; Gagalac, F. and Dunham, R. (2002): Cold tolerance of three strains of Nile Tilapia, Oreochromis niloticus, in China. Aquaculture., 213: $123-129$.

Soliman, A.M.H. (2015): The effect of Ethylenediamine -tetraacetic acid (EDTA) on growth performance of Nile Tilapia, Oreochromis niloticus. M.Sc. Thesis, Fac. Sci., Al- Azhar University., Pp: 167.

Soltan, M.; Hassaan, M. and Khattaby, A. (2016): Agricultural drainage water as a source of water for fish farming in Egypt. Ecology and Evolutionary Biology., $1(3): 68-75$.

Ssanyu, G.A., Rasowo, J., Auma, E., and Ndunguru, M. (2011): Evaluation of plankton community structure in fish refugia acting as Oreochromis niloticus. Propagation and Nursery Units for Rice/Fish Trials, Uganda. Journal of Aquaculture Research \& Development., 2(4): 100-116.

Sultana, T.; Haque, M.M.; Salam M.A. and Alam, M.M. (2017): Effect of aeration on growth and production of fish in intensive aquaculture system in earthen ponds. J. Bangladesh Agril. Univ. 15(1): 113-122.

Teichert-Coddington, D.R. (1996): Effect of stocking ratio on semi-intensive polyculture of Colossoma maropomum and Oreochromis niloticus in Honduras, Central America. Aquaculture., 143: 291-302.

Tukey, J. (1949): "Comparing Individual Means in the Analysis of Variance". Biometrics., 5 (2): 99-114.

Turano, M.J.; Borski, R.J. and Daniels, H.V. (2008): Effects of cyclic feeding on compensatory growth of hybrid striped bass, Morone chrysopsx and M. saxitilis food fish and water quality in production ponds. Aquaculture Research., 39: $1514-1523$. 


\section{ARABIC SUMMARY}

تأثير الكثافه العددية ومعدل التغذية علي جودة المياة ووفرة الهائمات النباتية لأسماك البلطى النيلى التئ المرباه فى الأحواض الترابية لإبية (Oreochromis niloticus)

، أحمد سنى الاين محمد صادق

$$
\begin{aligned}
& \text { إيناس جلا }
\end{aligned}
$$

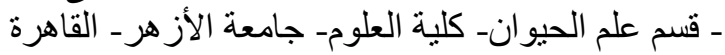

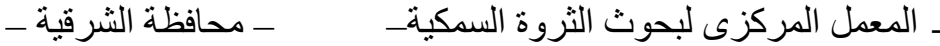

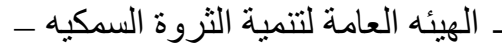

يههف هذا البحث إلى دراسه تأثثير كثافة التسكين ومعدل التغذية على جودة المياه ووفرة الهائمات النباتية

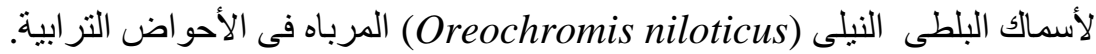

تم إجر اء التجربة بمزرعة برسيق، منطقة ادكو، محافظة البحيرة، جمهورية مصرية الأبر العربية والتجربة م مملوء بمياه

ـ تم تربية زريعة البلطي النيلي وحيد الجنس لمدة يوم بكثافات تخزينية مختلفة

ومعدلات تغذية مختلفة.

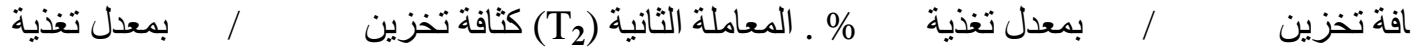

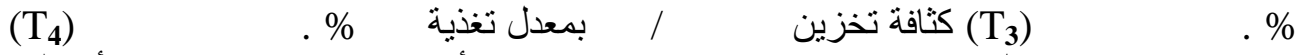

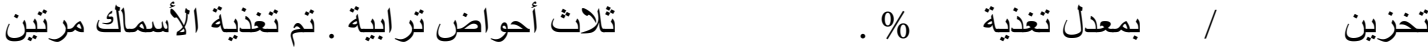

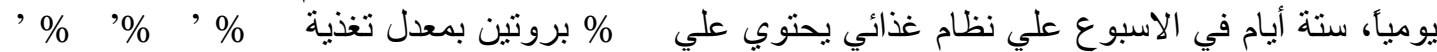

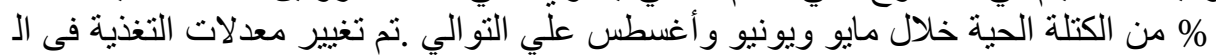

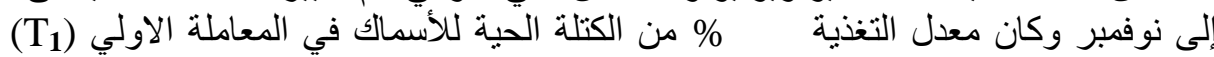

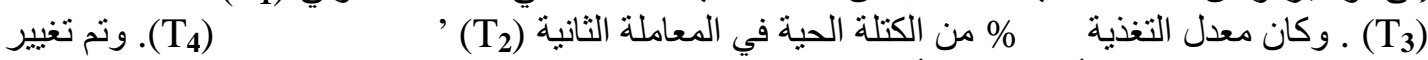

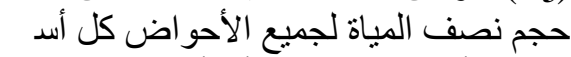

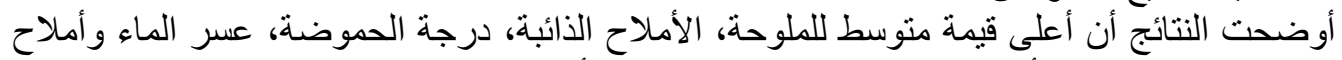

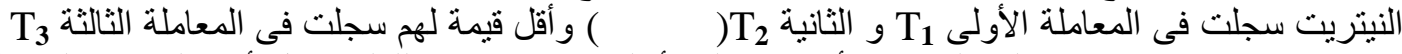
( ) T4

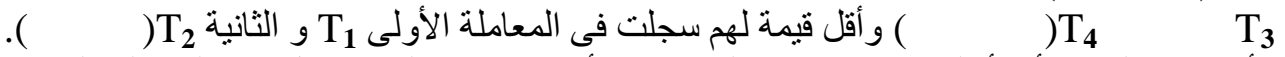

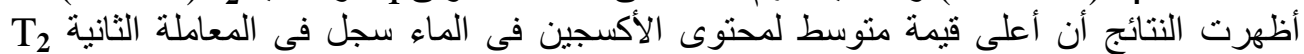

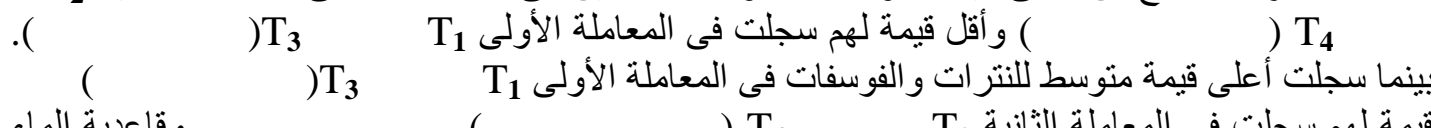

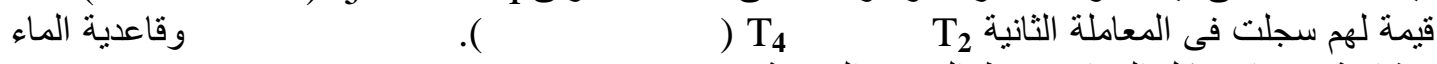

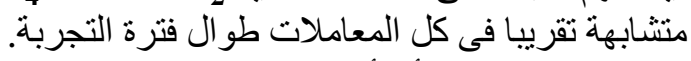

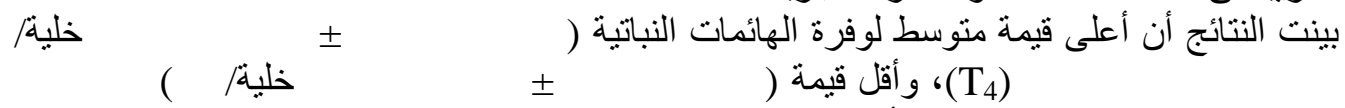

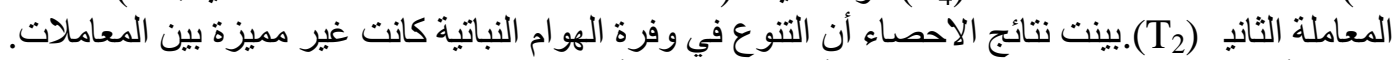

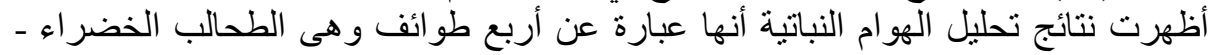
ـ الطحالب العصوية و اليوجلينات.

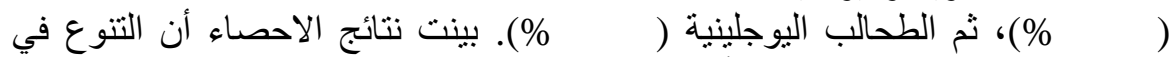

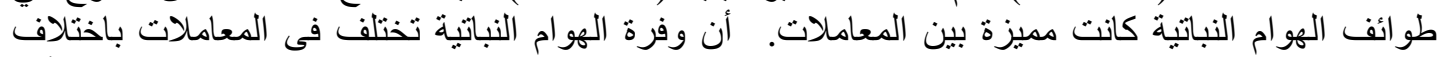

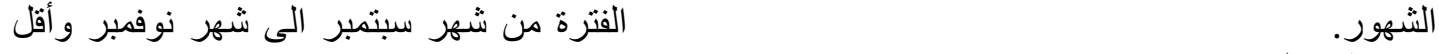

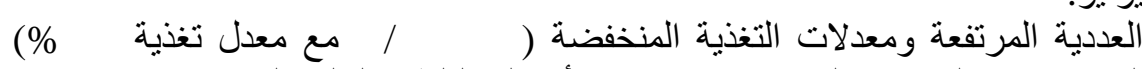
متوسط سجل في شهر يونيو.

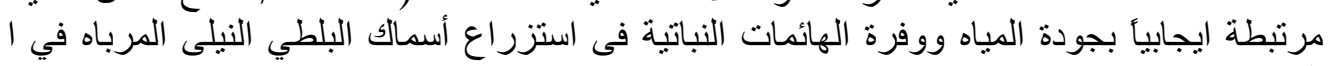
التر ابية. 